\title{
Structural changes in Medicago truncatula root nodules caused by short-term aluminum stress
}

\author{
Marzena Sujkowska-Rybkowska • Wojciech Borucki • \\ Ewa Znojek
}

Received: 28 August 2012 / Accepted: 4 December 2012 / Published online: 15 December 2012

(C) The Author(s) 2012. This article is published with open access at Springerlink.com

\begin{abstract}
Aluminum in the form of $\mathrm{Al}^{3+}$ is one of the most toxic heavy metal pollutants in nature and its effects are primarily root-related. Roots of Medicago truncatula exposed to $50 \mu \mathrm{M}$ of $\mathrm{AlCl}_{3}$ for $2 \mathrm{~h}$ and $24 \mathrm{~h}$ were examined by light and electron microscopy. Changes in the appearance of the host cells, infection threads and bacteroidal tissue occurred during the first $2 \mathrm{~h}$ of $\mathrm{Al}$ stress. Microscopic observations showed that aluminum: (1) induced thickening of plant cell and infection threads (ITs) walls, (2) stimulated IT enlargement, (3) caused disturbances in bacterial release from the ITs, (4) modified cell vacuolation and induced synthesis of granular material and its deposition in the cytoplasm, (5) and caused structural alterations of organella and bacteroids.
\end{abstract}

Keywords Aluminum toxicity $\cdot$ Medicago truncatula . Nodule $\cdot$ Rhizobia $\cdot$ Symbiotic nitrogen fixation

\section{Introduction}

Aluminum ( $\mathrm{Al})$ is one of the most important factors limiting crop production on acid soils (Liao et al. 2006). The easily observable symptom of Al toxicity is a rapid inhibition of root growth (Horst et al. 1992; Delhaize and Ryan 1995). The inhibition of root elongation of Al-sensitive corn can occur within 30 min of Al treatment (Llugany et al. 1995). The rapidity of this response indicates that Al quickly disrupts root cell expansion and elongation, prior to inhibiting cell division (Kochian et al. 2005). Al binds in the root

M. Sujkowska-Rybkowska $(\bowtie) \cdot$ W. Borucki $\cdot$ E. Znojek University of Life Sciences in Warsaw, Warsaw, Poland e-mail: marzena_sujkowska@sggw.pl apoplast to negatively charged sites of pectins (Taylor et al. 2000; Eticha et al. 2005; Rangel et al. 2009) leading to the displacement of $\mathrm{Ca}^{2+}$ and thereby reducing cell wall extensibility and inhibiting root growth (Ma et al. 2004). Al interferes with a wide range of physical and cellular processes. Al has a strong affinity for the negatively charged plasma membrane (PM) and causes depolarization of the PM (Ahn et al. 2001; Kochian et al. 2005). Furthermore, Alinduced reactive oxygen species (ROS) accumulation causes peroxidative damage to membrane lipids and oxidative stress (Yamamoto et al. 2001).

$\mathrm{Al}$ has also been shown to rapidly accumulate in the symplasm (Lazof et al. 1994) and in the nuclei of root tip cells (Silva et al. 2000). Binding of Al to the nuclei may inhibit mitotic activity via alterations in chromatin structure and DNA composition (Silva et al. 2000) or by affecting the mechanisms controlling the organization and polymerization of microtubules (Frantzios et al. 2005). Collectively, these findings demonstrate that $\mathrm{Al}$ has deleterious effects on various cellular components.

A majority of the research in the area of $\mathrm{Al}$ toxicity has focused on monocot crop species, while limited research has been conducted on legumes. The establishment and activity of the legume-Rhizobium symbiosis have both been found to be extremely sensitive to Al stress (Bordeleau and Provost 1994; Igual et al. 1997). Legumes treated with $\mathrm{Al}$ for a long period show decreased nodulation and nitrogenase activity (Alva et al. 1990; Shamssudin et al. 1992; Igual et al. 1997; Balestrasse et al. 2006). Al has been shown to adversely affect the nodulation process through inhibition of lateral root extension (Silva et al. 2001) and nodule initiation (Flis et al. 1993). To our knowledge, there are no reports concerning cytological changes in Medicago root nodules under Al stress. However, the model legume Medicago truncatula serves as an ideal model system to study $\mathrm{Al}$ toxicity and resistance mechanisms in legumes. 
Since long-term (measured days after the addition of $\mathrm{Al}$ ) responses are not directly caused by $\mathrm{Al}$, but might rather be a consequence of numerous other Al-related biochemical and physiological processes, they might be more misleading than short-term studies in determining the primary toxic effect of Al. The aim of the present study was to assess the effect of short-term aluminum stress on Medicago truncatula nodules structure. The effect of Al stress on nodule morphology and ultrastructure was examined using light and transmission electron microscopy.

\section{Materials and methods}

\subsection{Plant material and growth conditions}

Seeds of Medicago truncatula genotype A17 were scarified using concentrated sulfuric acid and surface sterilized with $5 \%(\mathrm{v} / \mathrm{v})$ bleach for 3 mins. The seeds were placed at $4{ }^{\circ} \mathrm{C}$ in sterile water for 1 day and germinated on $1 \%$ agar plates at room temperature (Bestel-Corre et al. 2002). Three-day old seedlings were then transplanted into $1 \mathrm{~L}$ plastic pots (five seeds per pot) containing a 2:1 (v/v) perlit:sand mixture and inoculated with Ensifer medicae WSM419. Ensifer medicae WSM419 was obtained from Professor Jason J. Terpolilli (Centre for Rhizobium Studies, Australia) and is fully effective with Medicago host (Terpolilli et al. 2008). Plants were grown under controlled environmental conditions (14-h photoperiod, $400 \mu \mathrm{mol}$ photons $\mathrm{m}^{-2} \mathrm{~s}^{-1}, 24{ }^{\circ} \mathrm{C} / 17{ }^{\circ} \mathrm{C}$ day/night regime, $70 \%$ relative humidity). The plants were watered three times a week with nitrogen-free Fahraeus (1957) medium and all solutions for plants were adjusted to $\mathrm{pH}$ 4.5 with $\mathrm{HCl}$. For $\mathrm{Al}$ treatment, four-week-old plants were treated with the Fahraeus medium supplemented with $50 \mu \mathrm{M} \mathrm{AlCl}$ for 2 and $24 \mathrm{~h}$. After the treatments, all the plants were washed with distilled water and root nodules were collected for examination.

\subsection{Light and electron microscopy (TEM) examination}

For light and TEM microscopy studies, hand sections of the nodules were fixed according to Karnovsky (1965) and embedded in glycid ether 100 epoxy resin (SERVA) (Borucki and Sujkowska 2008). Blocks were sectioned using microtomes (Jung RM 2065 and Ultracut UCT, Leica). Semithin sections were stained with methylene blue and azur A, and examined under a light microscope (Olympus-Provis, Japan). Thin sections were collected on copper grids and stained with uranyl acetate followed by lead citrate for $1 \mathrm{~min}$ and examined under a transmission electron microscope (Morgagni 268D).

\section{Results}

\subsection{Light microscopy}

The light microscopy examination showed that control (untreated) Medicago root nodules had the typical elongated shape and indeterminate structure with characteristic zonation of the bacteroidal tissue (Fig. 1a and b). From the distal to proximal part of the nodule, several zones can be distinguished, for example, the meristematic zone (M) composed of dividing cells, the infection thread penetration zone (Zone I), early symbiosis zone (Zone II), interzone with large amyloplasts (II/III), and late symbiotic zone (Zone III) (Sujkowska et al. 2011). When nodules get older, Zone IV, the senescence zone, in which cells are degenerated, is present (see also Vasse et al. 1990; van de Wiel 1991). The nodules were surrounded by peripheral tissues which consist of cortex, nodule endodermis and nodule parenchy$\mathrm{ma}$, in which nodule vascular bundles were located.

The anatomical structure of Al-treated nodules was similar to a control group (Fig. 1c to f) with minor differences. In Zone I, numerous, large infection threads were observed but the bacteria being released from the ITs were barely visible (Fig. 1d and f). Infected cells in Zone III showed numerous vacuoles instead of the single central vacuole observed in control nodules. Similar vacuolation occurred in the meristem and Zone I of Al-treated nodules (Fig. 1d and $\mathrm{f}$ ). In the meristem of Al-treated nodules, nuclei and nucleoli were enlarged (Fig. 1d and f). Necrotic cells were visible in all zones of Al-treated nodules (Fig. 1c and e). Additionally, nodule cortex cells were irregular in shape and enlarged (Fig. 1c and e).

\subsection{The influence of $\mathrm{Al}$ on the ultrastructure of $M$. truncatula root nodules (TEM)}

Disturbances in Al-treated nodules are more at the cytological than histological levels. Electron microscopic observations showed striking differences between the infection threads of control nodules and the Al-treated one (Fig. 2). Infection threads profiles of Al-treated nodules were otherwise altered in morphology, compared to normal infection threads (Fig. 2a, c and e). Independent of the time of $\mathrm{Al}$ stress, the infection threads of Medicago nodules were wide and harbored many more bacteria. Control infection threads were narrow, tubular structures with a thin, fibrillar wall (Fig. 2a and b). In contrast, the thick infection thread walls in Al-treated nodules consisted of many layers of fibrous material with numerous membrane invaginations (Fig. 2c and e). A copious, fibrillar matrix surrounded the bacteria within the thread. In Zone II a very broad range of IT grew and branched into threads surrounded by thick walls (Fig. 2c and e). Many infection threads developed into large, 
Fig. 1 LM micrographs of a longitudinal section of the 21day-old Medicago truncatula nodules. (a and b) Control without $\mathrm{Al}$, (c and d) $2 \mathrm{~h}$ and (e and f) $24 \mathrm{~h} \mathrm{Al}$ stress, respectively. Visible distinct zonation of the bacteroidal tissue: $\mathrm{M}$ meristem, I - infection thread penetration zone, II - early symbiosis zone, II/III - interzone with large amyloplasts, III - nitrogen fixation zone. Arrow - enlarged nuclei and nucleoli; arrowhead - the releasing bacteria from infection thread; asterisk - necrotic cells; c - cortical tissue; e - nodule endodermis; pa - parenchyma; $\mathrm{vb}$ - vascular bundle. (a)(c)(e) Scale bars $=100 \mu \mathrm{m}$. (b)(d)(f) Scale bars $=50 \mu \mathrm{m}$

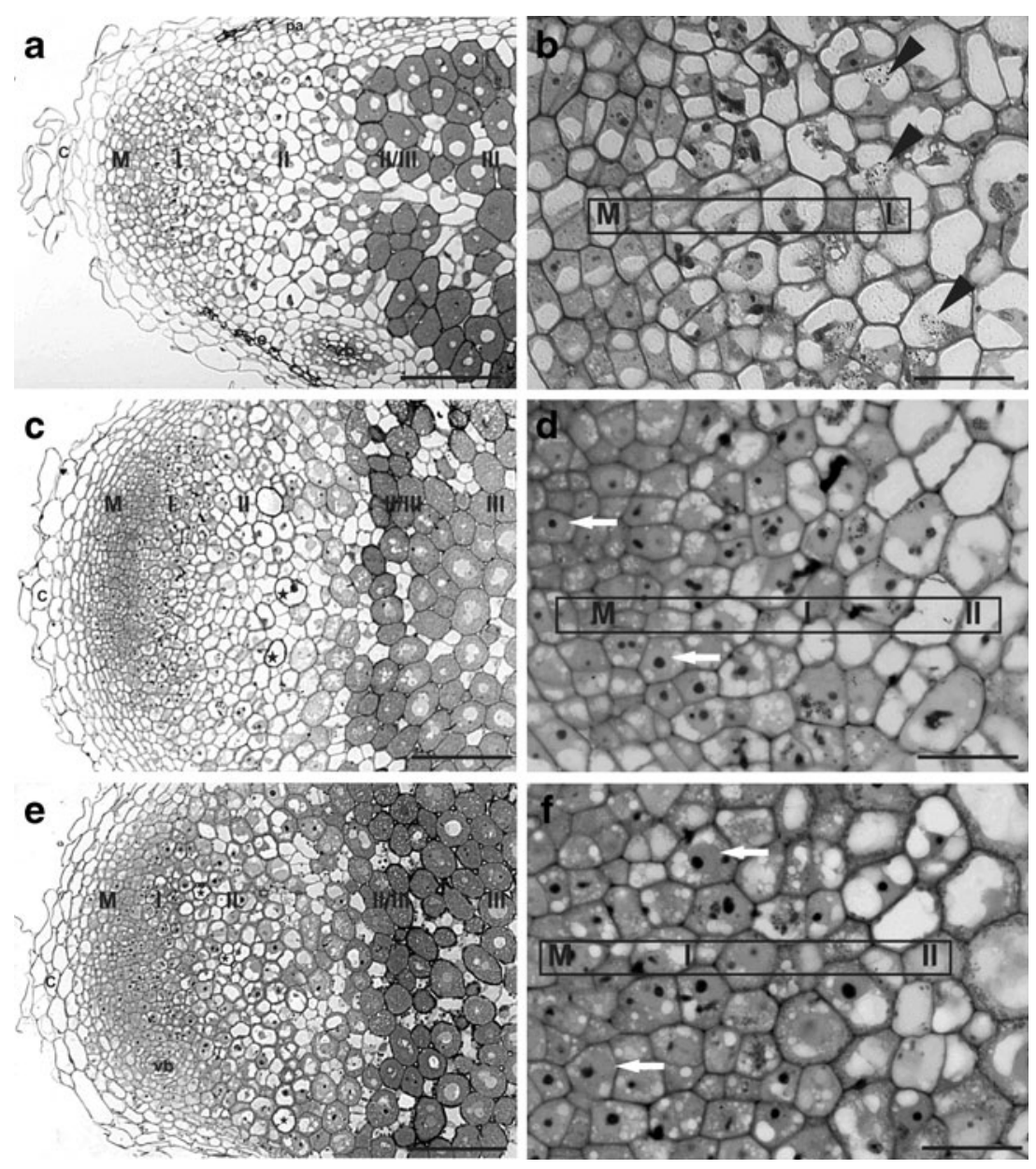

branched structures rather than typical tube-like structures observed in control nodules. In contrast to the control nodules, lateral bulges of the ITs in Al-treated nodules contained electron-dense deposition of IT wall material (Fig. 2c and e). The lateral bulges are supposed to be the initial infection droplets mediating the release of bacteria into the cytoplasm (Newcomb 1976). Release of bacteria from infection threads was also disturbed (Fig. 2d and f). Deformation of the peribacteroidal membranes of young bacteroids was frequently observed (Fig. 2d and f).

Meristematic and infected cells of $2 \mathrm{~h} \mathrm{Al-treated} \mathrm{nodules}$ showed numerous small vacuoles (Fig. $3 \mathrm{c}$ to $\mathrm{h}$ ) instead of a single central vacuole observed in control nodules (Fig. 3a and b). Vacuolar shrinkage was induced by $\mathrm{Al}$ treatment (Fig. $3 \mathrm{c}$ to h). Free space resulting from the shrinkage was filled by a granular material expanding from the cytoplasm territory (Fig. 3c to h). Prolonged Al treatment resulted in the almost total disappearance of vacuoles from Zone III (Fig. 3h). The material was usually located in the proximity of RER (Fig. 3d and e). In some cells, myelin-like structures occurred in the cytoplasm (Fig. 3g).

Aluminum did not significantly affect plastid structure. However, Al application produced alterations in the other organelles and bacteroids in Medicago nodules. In control nodules, mitochondria were abundant in the cytoplasm of meristem and infected cells, concentrated around cell walls and containing well-developed cristae (Fig. $4 \mathrm{a}$ and b). After $2 \mathrm{~h}$ of $\mathrm{Al}$ treatment, slight dilatation of mitochondria occurred. Decrease of matrix density started from the central part of the mitochondrion (Fig. 4c and d). After 24-hour Al stress, the mitochondria were enlarged with expanded cristae with a clear zone in the central area (Fig. 4e and f). Moreover, the breakdowns of mitochondrial membrane were frequently observed (Fig. 4f).

After $\mathrm{Al}$ treatment, the thickness of the plant cell wall increased (Fig. 4d and f). The plasma membrane showed numerous invaginations and many vesicles of different sizes appeared near the plant cell walls (Fig. 4d and f). Within the cytoplasm, dictyosomes generated many microvesicles (Fig. $4 \mathrm{~d}$ and $\mathrm{f}$ ). Numerous vesicles near the cell wall indicated the deposition of polysaccharidic material into walls via exocytosis. Al treatment changed the dictyosome structure in nodule cells (Fig. 5a to d). In control cells, the Golgi body had a typical morphology of five or six closely stacked cisternae asymmetrically differentiated from the cis to trans faces, with small secretion vesicles budding from the trans 
Fig. 2 TEM micrographs showing infection thread (ITs) structure and bacteria endocytosis in the apical part of Medicago nodules. (a) and (b) Typical thinwalled ITs from control nodules. (c to f) Abnormal ITs surrounded by thick walls in nodules after $2 \mathrm{~h}$ (c and d) and $24 \mathrm{~h}$ (e and f) of $\mathrm{Al}$ stress. Many ITs developed into large, branched structures. Note lateral bulges of the IT (arrow), which contain electron-dense depositions of IT wall material. Release of bacteria from ITs is probably disturbed. Deformation of peribacteroidal membranes of young bacteroids (arrowhead) is visible. The plant cytoplasm, in the vicinity of released bacteria, contains large number of vesicles. b - bacterium; ba - bacteroid; cw cell wall; $\mathrm{N}$ - nucleus; Nu- nucleolus; $\mathrm{m}$ - mitochondrion; RER rough endoplasmic reticulum; $\mathrm{w}$ infection thread wall; $\mathrm{v}$ - vacuole. Scale bars $=2 \mu \mathrm{m}$
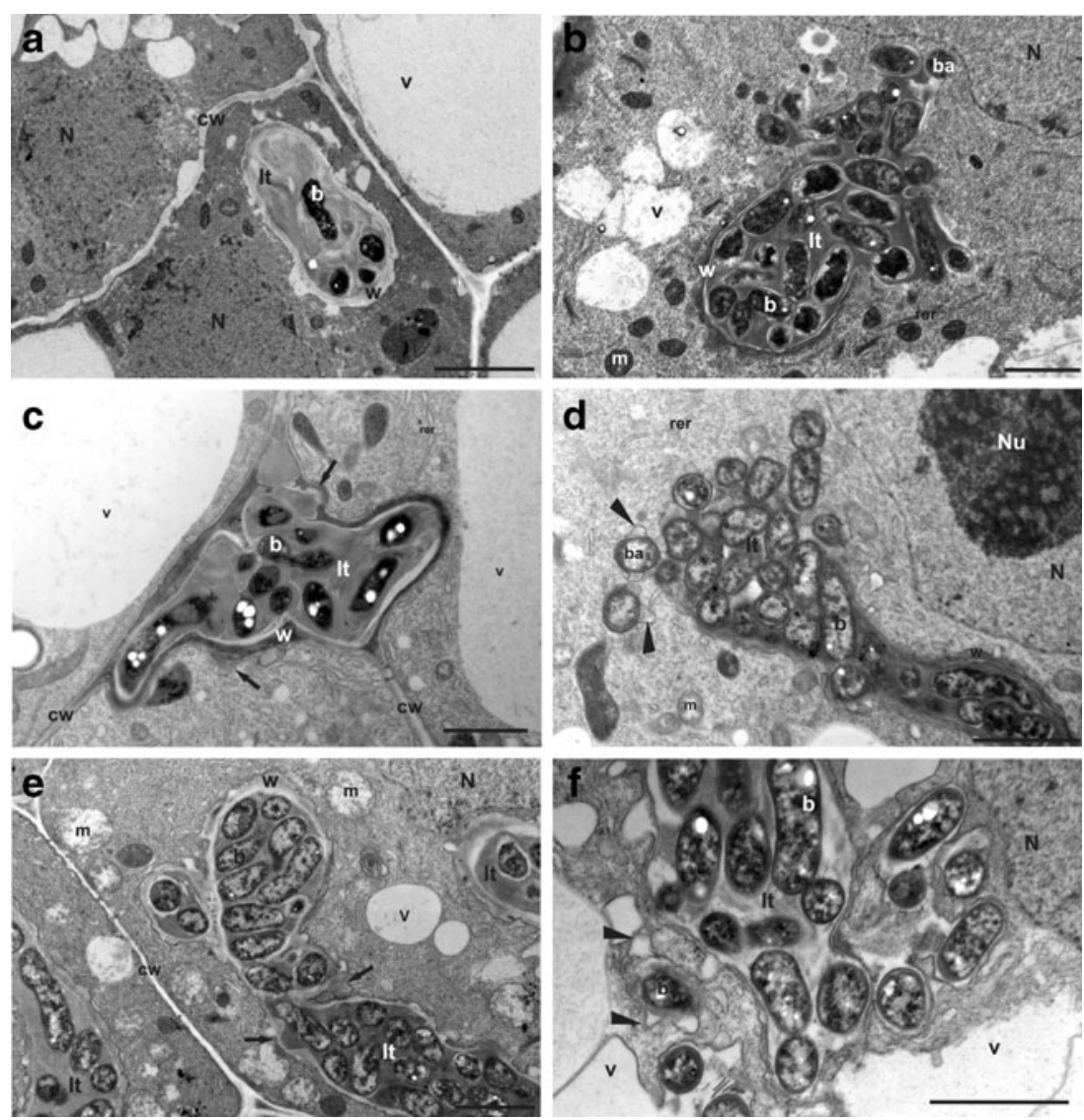

end (Fig. 5a). In stressed cells, the number of the cisternae was reduced compared to the control. The trans face was often observed with several adjacent translucent vesicles attached. These appeared to be enlarged vesicles which detached from the Golgi body (Fig. 5b). Prolonged Al treatment resulted in Golgi stack disintegration into small vesicles (Fig. $5 \mathrm{c}$ and d). Endoplasmic reticulum was also affected (Fig. 5e to g). After $2 \mathrm{~h}$, endoplasmic reticulum of infected and uninfected cells showed slight dilatation (Fig. 5e and f). Some RER form ring-shaped structures (Fig. 5e and f). RER swelling increased after 24-hour Al treatment. RER declined in quantity and became fragmentary (Fig. 5g). Al treatment induced nuclei and nucleoli enlargement in nodule cells (Fig. 5h). The nuclei, with one or two large nucleoli and very often irregularly lobed or with deep invaginations, were located in the central zone of the cell (Fig. 5h).

Aluminum significantly affects bacteroids structure (Fig. 5i to k). Young symbiosomes, just released from the IT, had balloon-shaped membrane protrusions (Fig. $2 \mathrm{~d}$ and f). 2-hour Al stress in the cells of Zone III reduced cell cytoplasm with clear symptoms of plasmolysis (Fig. 5j). Bacteroids displayed large peribacteroid spaces and translucent cytoplasm (Fig. 5j). After $24 \mathrm{~h}$ of Al stress nitrogenfixing bacteroids underwent degeneration, symbiosomes were irregular in shape and often enclosed inside a common peribacteroid membrane as the result of symbiosome fusion (Fig. 5k).

\section{Discussion}

Aluminum toxicity is one of the most deleterious factors for plant growth on acid soils (Liao et al. 2006). Plants growing in $\mathrm{Al}$ stress environment must have evolved mechanisms to increase their tolerance through both physical adaptations and interactive molecular and cellular changes.

In the present study, we showed that even short-term exposure time of Al was sufficient to disturb root nodule development, which was accompanied by perturbation in the infection process and premature bacteroidal tissue degeneration. The most obvious structural changes in nodules, $2 \mathrm{~h}$ after the exposure of seedlings to $50 \mu \mathrm{M}$ of $\mathrm{AlCl}_{3}$, were disturbances in IT growth, modified cell vacuolation, and organella and bacteroid degradation. Some symptoms of Al stress in nodules were similar to those described previously for roots (Wagatsuma et al. 1987; Marienfeld et al. 2000; Čiamporová 2000; Zheng and Yang 2005). After $24 \mathrm{~h}$ in the presence of the same concentration of $\mathrm{Al}$, the degree of the disorganization was enhanced.

$\mathrm{Al}$ either accumulates on the cell surface in the cell walls (Horst et al. 1997, 1999; Marienfeld et al. 2000; Wang et al. 
Fig. 3 TEM micrographs. Comparisons of the vacuolar behavior from control and Alstressed Medicago nodules. (a and b) control, (c and d) $2 \mathrm{~h} \mathrm{Al}$ stress, (e to h) 24 h Al stress. Central vacuoles in meristematic (a) and infected (b) cells from Zone III of control nodules. c Granular material (black arrows) presses down the vacuole. d Visible vacuolereplacing granular material (black asterisk) near the cisternae of rough endoplasmic reticulum (RER). Membranous material is visible in the central vacuole (arrowhead). e Cells with vanishing central vacuoles replaced by granular material (black asterisk). f Infected (IC) and uninfected (UC) cells with shrinkage vacuoles and vacuole-replacing granular material (black asterisk). g Fragment of uninfected cell containing myelin-like structure (white asterisk) and lobed nucleus (white arrow). h Shrunk vacuoles with granular material (black asterisk) in cell of Zone III. ba - bacteroid; cw - cell wall; $\mathrm{m}$ - mitochondrion; $\mathrm{N}$ nucleus; $\mathrm{Nu}$ - nucleolus; $\mathrm{p}$ plastid; $\mathrm{s}$ - starch granule; $\mathrm{v}$ vacuole. Scale bars $=1 \mu \mathrm{m}$
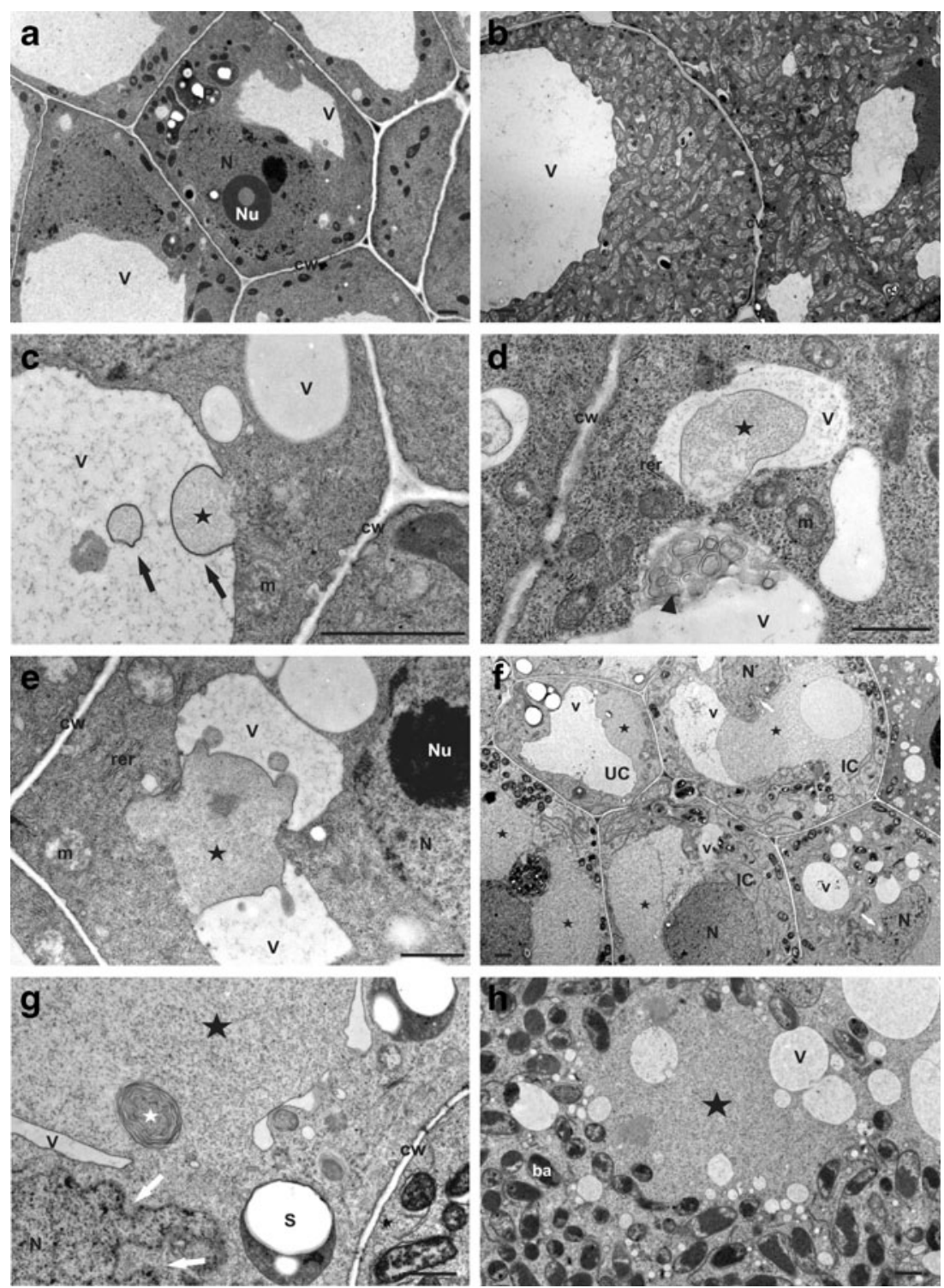

2004) or it enters the cells (Tice et al. 1992; Silva et al. 2000; Jones et al. 2006) during exposure to Al. Cell walls and intercellular spaces, the so-called apoplast, are the first compartments of the root that come into contact with the potentially toxic Al species present in the soil solution. Many studies have shown that most of the $\mathrm{Al}$ that accumulates in roots corresponds to $\mathrm{Al}$ in this apoplastic space (Heim et al. 1999). Extracellular aluminum is mainly associated with cell wall pectins, as the correlation between the pectin content in the cell walls and the accumulation of $\mathrm{Al}$ suggests (Horst et al. 1999; Schmohl and Horst 2000; Hossain et al. 2006). The nodule peripheral cortex tissue and IT are especially sensitive to Al. The walls of plant cells and walls of IT in nodules treated with Al were thickened, which correlates with previous studies in roots (Budíková et al. 1997). Cell wall thickening and the disturbances in IT growth occurring in Al-treated nodules might be a result of stiffening of polysaccharide network. Teraoka et al. (2002) suggest that $\mathrm{Al}$ modifies the metabolism of cell wall components and thus makes the cell wall thick and rigid. $\mathrm{Al}$ stress has been shown to increase the amounts of certain cell wall components (e.g. hemicelluloses, polysaccharides, glycoproteins, callose, lignin) (Sasaki et al. 1996; Horst et al. 1999; Sivaguru et al. 2000; Teraoka et al. 2002; Jones et al. 2006), which causes cell wall thickening and prevents $\mathrm{Al}$ from entering the plasma membrane. The binding of Al to the newly formed wall material may lead to a decrease in the mechanical properties of the walls, thus hampering cell elongation (Ma et al. 2004; Jones et al. 2006).

$\mathrm{Al}$ treatment has a profound effect on IT morphology. The development of large and strongly branched ITs surrounded by thicker walls than in control nodules was observed. Similar modifications of IT walls have been described for pea and Medicago mutants (Novak et al. 

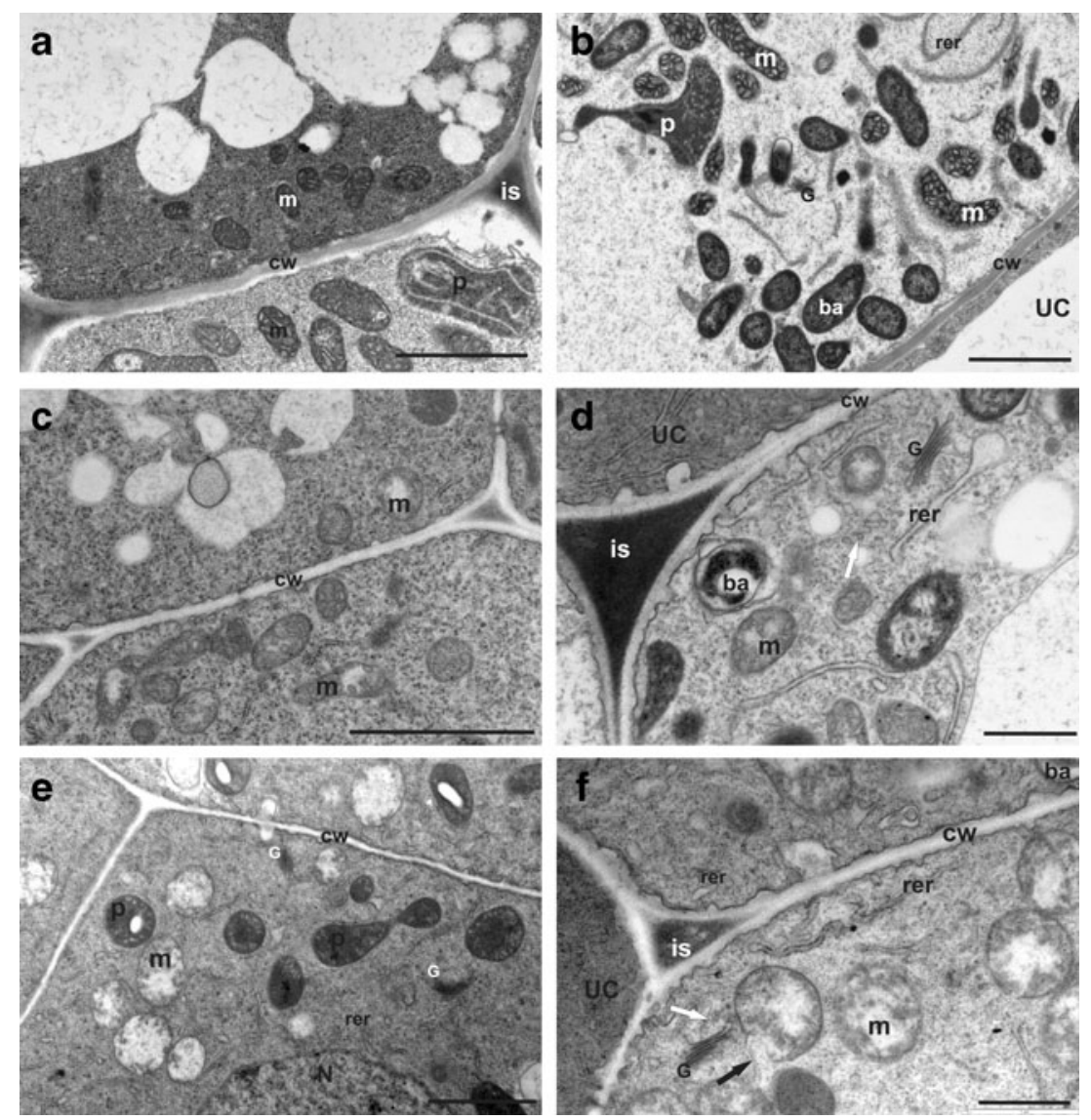

Fig. 4 TEM micrographs. Structural alterations of plant cell walls and mitochondria of control (a and b), $2 \mathrm{~h} \mathrm{(c} \mathrm{and} \mathrm{d)} \mathrm{and} 24 \mathrm{~h} \mathrm{(e} \mathrm{and} \mathrm{f)} \mathrm{Al-}$ treated nodules. Numerous typical, small mitochondria near thin plant cell walls (cw) in meristematic cells (a) and infected cell from the Zone II (b). Mitochondria possess distinct cristae uniformly distributed within electron-dense matrix. c and (d) Mitochondria matrix of meristematic (c) and infected cell from the Zone II (D) become electron translucent. Visible mitochondria with globular cristae near thickened plant cell wall (cw). e and (f) Mitochondria of meristematic (e) and

1995) and pseudonodules formed by Ensifer meliloti (EPSI)-deficient mutants (Niehaus et al. 1993). Wall thickening seems to be a common response of plant cells to $\mathrm{Al}$ stress. Thick walls can cause disturbances in the bacteria release from the ITs. Hypertrophied ITs, like those observed in the Zone I of Al-treated nodules, have previously been described in several other instances, for example "prominent" IT were seen in the ineffective fababean nodules (Haser et al. 1992), enlarged IT were also reported in pseudonodules (Niehaus et al. 1993) and large invasion structures formed by LPS-defective mutants of Rhizobium leguminosarum bv. viciae (Peretto et al. 1994). Alteration of IT morphology caused by $\mathrm{Al}$ stress may be a result of IT wall and matrix modifications.

In this study, $\mathrm{Al}$ has profound effects on the vacuolar system (Fig. 3). Vacuolation of the cytoplasm has been commonly observed in stressed plant root cells (Čiamporová

infected cell from the Zone II (f) are enlarged and their cristae are not well distinguished. The central parts of mitochondria are electrontranslucent with fibrillar material. Notice the breakdown of the mitochondrial envelope (black arrow). Visible numerous secretory vesicles derived from Golgi complex in close proximity to the thickened cell wall (white arrow). ba - bacteroid; cw - cell wall; G - Golgi complex; $\mathrm{m}$ - mitochondrion; N - nucleus; RER - rough endoplasmic reticulum; Is - intercellular space; $p$ - plastid; UC - uninfected cells. Scale bars $=2 \mu \mathrm{m}$

2002; Alvarez et al. 2012). Progressive vacuolation in the cells of barley roots (Ikeda and Tadano 1993), in meristematic tissue of oat (Arena sativa) (Marienfeld et al. 1995), and also in tobacco (Nicotiana tabacum) cells (Panda et al. 2008) have been seen under Al stress. This structural change may be attributed to the induction of a defense mechanism in cells. The increased volume of vacuoles may be important for sequestration of toxic ions such as $\mathrm{Al}^{3+}$ (Vázquez et al. 1999; Illéš et al. 2006). In corn, this relied on the active transport of $\mathrm{Al}$ from the cell wall to vacuoles (Zheng and Yang 2005), and in other studies, higher vacuolation was observed in the root cap, epidermis, and root cortex (Vázquez et al. 1999; Čiamporová 2002). However, the vacuolar system in nodules is different. In response to $\mathrm{Al}$, vacuoles seemed to lose turgor and shrink (Fig. 3). The free space that appeared after vacuole shrinkage was filled with a granular material formed on the cytoplasm territory. Numerous cisternae of 
Fig. 5 TEM micrographs

showing structural alterations of organelles and bacteroids in Alstressed nodules. Control (a and i), $2 \mathrm{~h}$ (b, e and f) and $24 \mathrm{~h} \mathrm{(c,} \mathrm{d,}$ $\mathbf{g}, \mathbf{h}$ and $\mathbf{k})$ Al-treated nodules. a Golgi complex (g) of control nodules. $\mathbf{b}$ to $\mathbf{d}$ Visible dictyosomes with decreased number of cisternae or disintegrated into numerous small vesicles. e and f Note a circular pattern of endoplasmic reticulum (RER) cisternae. g Swollen and fragmentary RER. h Enlarged, lobed nucleus with nucleolus $(\mathrm{Nu})$ in $24 \mathrm{~h} \mathrm{Al-treated} \mathrm{infected}$ cell of Medicago nodule. i Image of Zone III in control nodules. $\mathbf{j}$ and $\mathbf{k}$ Images of Zone III in Al-treated nodules showing infected cell with electrondense cytoplasm and degenerated bacteroids. Bacteroids displayed large peribacteroid spaces and translucent cytoplasm. There are numerous breaks in the peribacteroid membranes (arrows). Symbiosome fusion is observed. ba bacteroids; cw - cell wall; G Golgi complex; m - mitochondria; is - intercellular space; N nucleus; $\mathrm{Nu}$ - nucleolus; $\mathrm{p}$ plastid; pbs - peribacteroidal space; $\mathrm{s}$ - starch granule; UC uninfected cells; v- vacuole. Scale bars $=2 \mu \mathrm{m}$
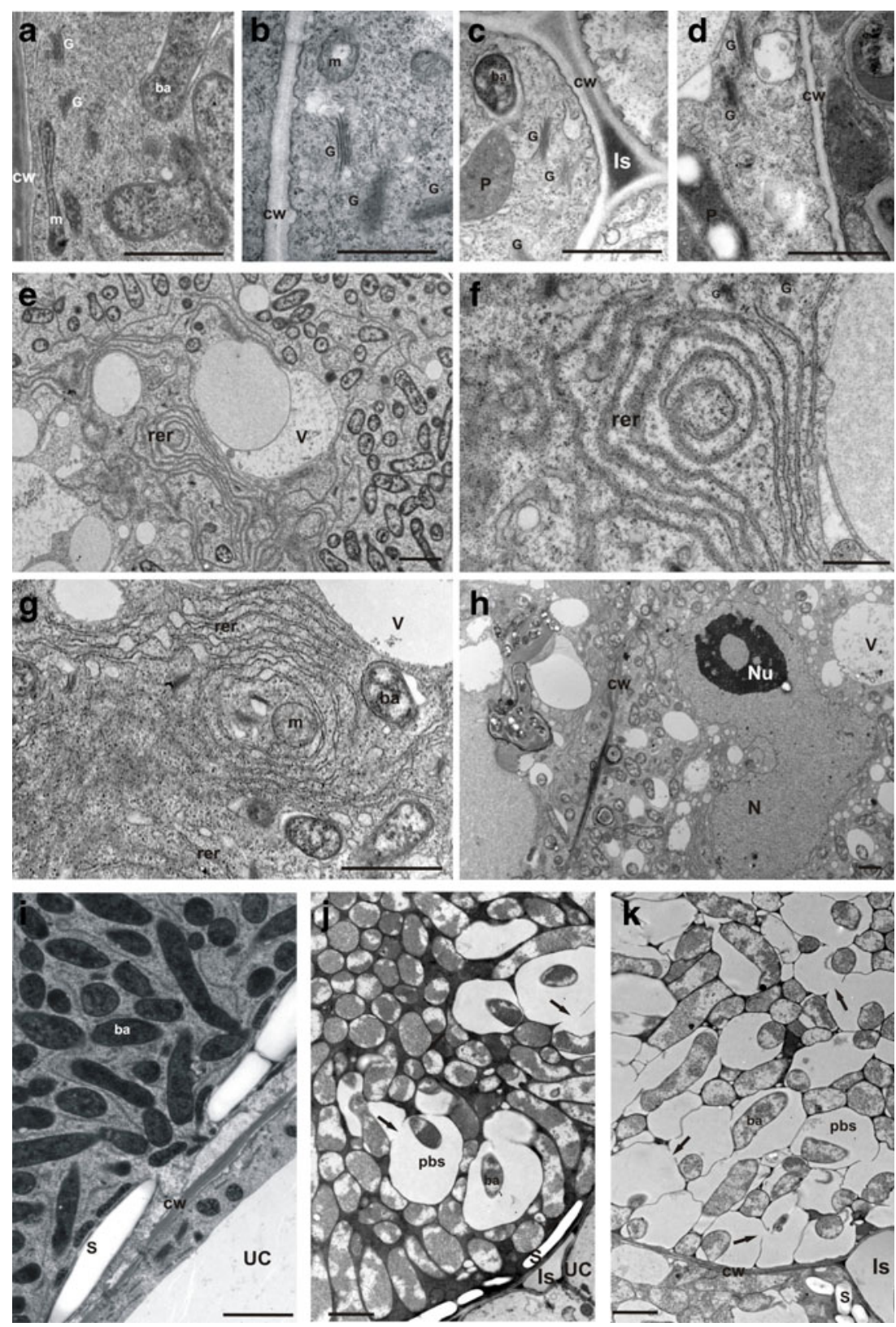

rough endoplasmic reticulum (RER) were located in the vicinity of the granular material, suggesting their involvement in its synthesis. Finally, after longer Al stress, granular material replaced shrinking vacuoles completely. Involvement of RER in the production of this material may indicate its protein-like nature. The presence of myelin-like structures in Al-treated nodules may be the result of the excess tonoplast formed during the shrinkage of vacuoles.

In present study, mitochondria appeared to be the organelle most affected by Al toxicity. The mitochondria exhibited abnormalities, such as swelling of mitochondria, decreased mitochondrial matrix density, cristae breakage, and sometimes bursting of the outer membrane (Fig. 4). The observed changes in the structure of mitochondria have been previously described in various plants and cell lines exposed to anaerobic conditions (Vartapetian et al. 2003), chilling injury (Lee et al. 2002), water deficit, as well as salt and temperature (Čiamporová and Mistrík 1993; Pareek et al. 1997), cadmium (Gzyl et al. 2009) and aluminum (Panda et al. 2008) stresses. In this study, observed ultrastructural changes in mitochondria of nodule cells may be the symptoms of stress-associated alterations in energy status. Legume nodules contain a wide array of antioxidant enzymes, many of which have been linked with stress-induced (and natural) senescence (Becana et al. 2000). Stress in nodules, including $\mathrm{Al}$ treatment, increases the activity of antioxidant enzymes and production of reactive oxygen species (ROS) (Sujkowska-Rybkowska 2012). Mitochondria play a key 
role in cellular metabolism and also in the regulation of programmed cell death (PCD). Panda et al. (2008) suggest a novel mechanism of Al toxicity that results in PCD via the mitochondria in tobacco cells. An increase in ROS production in mitochondria under $\mathrm{Al}$ treatment resulted in the opening of mitochondrial permeability transition pores. This result was further substantiated by TEM microscopy of mitochondria from control and Al-treated cells. Great numbers of swollen mitochondria with many vacuoles, blebbing out of plasma membrane from the cell wall, and preapoptotic nuclear structures were some of the characteristic features of Al-treated cells, confirming that aluminum signaling follows the mitochondrial pathway of cell death in tobacco cells (Panda et al. 2008). Similar nucleus changes were observed in Al-treated nodules. Short-term Al treatment changed nuclear morphology (lobed nucleus) and induced nuclei and nucleoli enlargement in nodule cells (Figs. 3e to $\mathrm{g}$ and $5 \mathrm{~h}$ ). The enlargement of these organelles indicated high metabolic activity of the nodule cells under $\mathrm{Al}$ stress.

The RER lamellae underwent fragmentation and dilatation in response to $\mathrm{Al}$ (Fig. 5). Furthermore, ribosomes were prominently attached to RER lamellae. Such prominent RER changes have been noted in response to stress conditions in various plants, which may possibly reflect the induction of stress proteins (Čiamporová and Mistrík 1993). In the cells of Medicago nodules, Golgi bodies are sensitive to $\mathrm{Al}$ (Fig. 5). Structural modifications, such as disintegration of Golgi cisternae, together with a lower frequency of Golgi bodies in the cells, may lead to reduction of secretion. In the Al-treated root cap cells, a lower frequency of Golgi bodies results in a decreased mucilage secretion (Kawano et al. 2003). Similar changes of the Golgi apparatus in root cells were observed under aluminum stress (Čiamporová 2000) and water deficit (Čiamporová and Mistrík 1993).

Aluminum induced early degeneration of nitrogenfixing bacteroids (Fig. 5). The senescence process had reached the final stages found in older control nodules (about 40 dpi) (Vasse et al. 1990; van de Wiel 1991). The degeneration of bacteroids shared some structural features with the normal senescence pattern of bacteroids in legume nodules (Hernández-Jiménez et al. 2002). The cytoplasm of senescent nodule cells becomes progressively less electron-dense and numerous vesicles appear. The symbiosomes change in size and shape as the bacteroid deteriorates. Membrane damage, particularly to the symbiosome membrane, appears to occur early in the senescence process. For example, biochemical and cytological evidence from soybean, French bean and Medicago nodules indicates that the symbiosome membrane may be the first target for degradation in the nodule senescence process (Puppo et al. 2005). However, the breakdown of the symbiosome membrane in lupins was only observed at a very advanced stage of senescence
(Hernández-Jiménez et al. 2002). At any stage, a rupture of this membrane is likely to be deleterious to nodule function, because regulated metabolite and signal exchange between the partners will be lost. The induction of senescence by $\mathrm{Al}$ is a complex process and different factors are involved including nutritional disturbances that can affect important metabolic processes.

In conclusion, the observations have confirmed that Medicago root nodules are very sensitive to Al stress. Short-term Al treatment modified cell vacuolation, induced wall thickening, and caused structural alterations of organelles and premature degeneration of bacteroids. To the authors' knowledge, this is the first report which shows the fast shrinkage of vacuoles across Medicago nodules with the simultaneous synthesis of granular vacuoles replacing material in the cytoplasm after Al treatment. In addition, the current study demonstrates Al-induced infection thread wall thickening, which may be responsible for the disturbances in infection thread growth and bacteria release. Therefore, further research should include physiological processes likely to be associated with Al tolerance in Medicago. For example, studies of $\mathrm{Al}$-induced protein synthesis and activities of the antioxidant defense system may give new insight into the mechanisms of $\mathrm{Al}$ tolerance.

Open Access This article is distributed under the terms of the Creative Commons Attribution License which permits any use, distribution, and reproduction in any medium, provided the original author(s) and the source are credited.

\section{References}

Ahn SJ, Sivaguru M, Osawa H, Chung GC, Matsumoto H (2001) Aluminum inhibits the $\mathrm{H}^{+}$-ATPase activity by permanently altering the plasma membrane surface potentials in squash roots. Plant Physiol 126:1381-1390

Alva AK, Asher CJ, Edwards DG (1990) Effect of solution pH, external calcium concentration, and aluminium activity on nodulation and early growth of cowpea. Aust J Agric Res 41:359-365

Alvarez I, Sam O, Reynaldo I, Testillano P, Risueno CM, Arias M (2012) Morphological and cellular changes in rice roots (Oryza sativa $\mathrm{L}$.) caused by $\mathrm{Al}$ stress. Bot Stud 53:67-73

Balestrasse KB, Gallego SM, Tomaro ML (2006) Aluminium stress affects nitrogen fixation and assimilation in soybean (Glycine max L.). Plant Growth Regul 48:271-281

Becana M, Dalton DA, Morana JF, Iturbe-Ormaetxea I, Matamorosa MA, Rubio MC (2000) Reactive oxygen species and antioxidants in legume nodules. Physiol Plant 109:372-381

Bestel-Corre G, Dumas-Gaudot E, Poinsot V, Dieu M (2002) Proteome analysis and identification of symbiosis-related proteins from Medicago truncatula Gaertn. by two dimensional electrophoresis and mass spectrometry. Electrophoresis 23:122-137

Bordeleau LM, Provost D (1994) Nodulation and nitrogen fixation in extreme environments. Plant Soil 161:115-125

Borucki W, Sujkowska M (2008) The effects of sodium chloride salinity upon growth, nodulation, and root nodule structure of pea (Pisum sativum L.) plants. Acta Physiol Plant 30:293-301 
Budiková S, Čiamporová M, Ovečka M, Polónyi J (1997) Structural characterization of maize root tip cells under aluminium stress. Acta Fac Rer Nat Univ Com Physiol Plant 29:47-52

Čiamporová M (2000) Diverse responses of root cell structure to aluminum stress. Plant Soil 226:113-116

Čiamporová M (2002) Morphological and structural responses of plant roots to aluminium at organ, tissue, and cellular levels. Biol Plant 45:161-1741

Čiamporová M, Mistrík I (1993) The ultrastructural response of root cells to stressful conditions. Environ Exp Bot 33:11-26

Delhaize E, Ryan PR (1995) Aluminum toxicity and tolerance in plants. Plant Physiol 107:315.321

Eticha D, Staß A, Horst WJ (2005) Cell-wall pectin and its degree of methylation in the maize root-apex: significance for genotypic differences in aluminium resistance. Plant Cell Environ 28:1410-1420

Fahraeus G (1957) The infection of clover root hairs by nodule bacteria studied by single glass slide technique. J Gen Microbiol 16:374381

Flis SE, Glenn AR, Dilworth MJ (1993) The interaction between aluminium and root nodule bacteria. Soil Biol Biochem 25:403417

Frantzios G, Galatis B, Apostolakos P (2005) Aluminium causes variable responses in actin filament cytoskeleton of the root tip cells of Triticum turgidum. Protoplasma 225:129-140

Gzyl J, Przymusiński R, Gwóźdź EA (2009) Ultrastructure analysis of cadmium-tolerant and -sensitive cell lines of cucumber (Cucumis sativus L.). Plant Cell Tiss Organ Cult 99:227-232

Haser A, Robinson DL, Duc G, Vance CP (1992) A mutation in Vicia faba results in ineffective nodules with impaired bacteroid differentiation and reduced synthesis of late nodulins. J Exp Bot 43:1397-1407

Heim A, Luster J, Brunner I, Frey B, Frossard E (1999) Effects of aluminium treatment on Norway spruce roots: aluminium binding forms, element distribution, and release of organic substances. Plant Soil 216:103-116

Hernández-Jiménez MJ, Lucas MM, de Felipe MR (2002) Antioxidant defense and damage in senescing lupin nodules. Plant Physiol Biochem 40:645-657

Horst WJ, Asher CJ, Cakmak I, Szulkiewica P, Wissemeier AH (1992) Short-term responses of soybean roots to aluminum. J Plant Physiol 140:174-178

Horst WJ, Püschel AK, Schmohl N (1997) Induction of callose formation is a sensitive marker for genotypic aluminium sensitivity in maize. Plant Soil 192:23-30

Horst WJ, Schmohl N, Kollmeier M, Baluška F, Sivaguru M (1999) Does aluminum effect root growth of maize through interaction with the cell wall - plasma membrane - cytoskeleton continuum? Plant Soil 215:163-174

Hossain AKMZ, Hossain MA, Asgar MA, Tosaki T, Koyama H, Hara $\mathrm{T}$ (2006) Changes in cell wall polysaccharides and hydroxycinnamates in wheat roots by aluminum stress at higher calcium supply. J Plant Nutr 29:601-613

Igual JM, Rodriguez-Barrueco C, Cervantes E (1997) The effects of aluminium on nodulation and symbiotic nitrogen fixation in $\mathrm{Ca}$ suarina cunninghamiana Miq. Plant Soil 190:41-46

Ikeda H, Tadano T (1993) Ultrastructural changes of the root tip cells in barley induced by a comparatively low concentration of aluminum. Soil Sci PI Nutr 39:109-117

Illéš P, Schlicht M, Pavlovkin J, Lichtscheidl I, Baluška F, Ovecka M (2006) Aluminium toxicity in plants: internalization of aluminium into cells of the transition zone in Arabidopsis root apices related to changes in plasma membrane potential, endosomal behavior, and nitric oxide production. J Exp Bot 57:4201-4213

Jones DL, Blancaflor EB, Kochian LV, Gilroy S (2006) Spatial coordination of aluminium uptake, production of reactive oxygen species, callose production and wall rigidification in maize roots. Plant Cell Environ 29:1309-1318

Karnovsky MJ (1965) A formaldehyde-glutaraldehyde fixative of high osmolality for use in electron microscopy. J Cell Biol 27:137A$138 \mathrm{~A}$

Kawano T, Kadono T, Furuichi T, Muto S, Lapeyrie F (2003) Aluminum induced distortion in calcium signaling involving oxidative bursts and channel regulation in tobacco BY-2 cells. Biochem Biophys Res Commun 308:35-42

Kochian LV, Piñeros MA, Hoekenga OA (2005) The physiology, genetics and molecular biology of plant aluminum resistance and toxicity. Plant Soil 274:175-195

Lazof DB, Goldsmith JG, Rufty TW, Linton RW (1994) Rapid uptake of aluminum into cells of intact soybean root tips. A microanalytical study using secondary ion mass spectrometry. Plant Physiol 106:1107-1114

Lee SH, Singh AP, Chung GC, Kim YS, Kong IB (2002) Chilling root temperature causes rapid ultrastructural changes in cortical cells of cucumber (Cucumis sativus L.) root tips. J Exp Bot 53:2225-2237

Liao H, Wan H, Shaff J, Wang X, Yan X, Kochian LV (2006) Phosphorus and aluminum interactions in soybean in relation to aluminum tolerance. Exudation of specific organic acids from different regions of the intact root system. Plant Physiol 141:674-684

Llugany M, Poschenrieder C, Barceló J (1995) Monitoring of aluminium-induced inhibition of root elongation in four maize cultivars differing in tolerance to aluminium and proton toxicity. Physiol Plant 93:265-271

Ma JF, Shen RF, Nagao S, Tanimoto E (2004) Aluminum targets elongating cells by reducing cell wall extensibility in wheat roots. Plant Cell Physiol 45:583-589

Marienfeld S, Lehmann H, Stelzer R (1995) Ultrastructural investigations and EDX-analyses of Al-treated oat (Avena sativa) roots. Plant Soil 171:167-173

Marienfeld S, Schmohl N, Klein M, Schröder WH, Kuhn AJ, Horst WJ (2000) Localization of aluminium in root tips of Zea mays and Vicia faba. J Plant Physiol 156:666-671

Newcomb (1976) A correlated light and electron microscopic study of symbiotic growth and differentiation in Pisum sativum root nodules. Can J Bot 54:2163-2186

Niehaus K, Kapp D, Pűhler A (1993) Plant defense and delayed infection of alfalfa pseudonodules induced by expolysaccharide (EPS-I) deficient Rhizobium meliloti mutant. Planta 190:415-425

Novak K, Pesina K, Nebesarova J, Skrdleta V, Lisa L, Nasinec V (1995) Symbiotic tissue degradation in the ineffective nodules of three nodulation mutants of pea (Pisum sativum L.). Ann Bot 76:303-313

Panda SK, Yamamoto Y, Kondo H, Matsumoto H (2008) Mitochondrial alterations related to programmed cell death in tobacco cells under aluminium stress. C R Biol 331:597-610

Pareek A, Singla SL, Grover A (1997) Short-term salinity and high temperature stress-associated ultrastructural alterations in young leaf cells of Oryza sativa L. Ann Bot 80:629-639

Peretto S, Brewin N, Kannenberg EL (1994) Cytological evidence for a host-defense response that reduces cell and tissue invasion in pea nodules by lipopolysaccharide- defective mutants of Rhizobium leguminosarum strain 3841. Mol Plant-Microbe Interact 7:99-112

Puppo A, Groten K, Bastian F, Carzaniga R, Soussi M, Lucas MM, De Felipe MR, Harrison J, Vanacker H, Foyer CH (2005) Legume nodule senescence: roles for redox and hormone signalling in the orchestration of the natural aging process. New Phytol 165:683-701

Rangel AF, Rao IM, Horst WJ (2009) Intracellular distribution and binding state of aluminum in root apices of two common bean (Phaseolus vulgaris) genotypes in relation to $\mathrm{Al}$ toxicity. Physiol Plant 135:162-173 
Sasaki M, Yamamoto Y, Matsumoto H (1996) Lignin deposition induced by aluminum in wheat (Triticum aestivum) roots. Physiol Plant 96:193-198

Schmohl N, Horst WJ (2000) Cell wall pectin content modulates aluminium sensitivity of Zea mays (L.) cells grown in suspension culture. Plant Cell Environ 23:735-742

Shamssudin ZH, Kasran R, Edwards DG, Blamey FPC (1992) Effect of calcium and aluminum on nodulation, nitrogen fixation and growth of groundnut in solution culture. Plant Soil 144:273-2799

Silva IR, Smyth J, Moxley DF, Carter TE, Allen NS, Rufty TW (2000) Aluminum accumulation at nuclei of cells in the root tip: fluorescence detection using lumogallion and confocal laser scanning microscopy. Plant Physiol 123:543-552

Silva IR, Smyth TJ, Raper CD, Carter TE, Rufty TW (2001) Differential aluminum tolerance in soybean: an evaluation of the role of organic acids. Physiol Plant 112:200-210

Sivaguru M, Fujiwara T, Samaj J, Baluška F, Yang Z, Osawa H, Maeda T, Mori T, Volkmann D, Matsumoto H (2000) Aluminum-induced $1,3-\beta$-d-glucan inhibits cell-to-cell traffiking of molecules through plasmodesmata. A new mechanism of aluminum toxicity in plants. Plant Physiol 124:991-1005

Sujkowska M, Górska-Czekaj M, Bederska M, Borucki W (2011) Vacuolar organization in the nodule parenchyma is important for the functioning of pea root nodules. Symbiosis 54:1-16

Sujkowska-Rybkowska M (2012) Reactive oxygen species production and antioxidative defense in pea (Pisum sativum L.) root nodules after short-term aluminum treatment. Acta Physiol Plant 34:1387-1400

Taylor GJ, McDonald-Stephens JL, Hunter DB, Bertsch PM, Elmore D, Rengel Z, Reid RJ (2000) Direct measurement of aluminum uptake and distribution in single cells of Chara corallina. Plant Physiol 123:987-996
Teraoka T, Kaneko M, Mori S, Yoshimura E (2002) Aluminum rapidly inhibits cellulose synthesis in roots of barley and wheat seedlings. J Plant Physiol 159:17-23

Terpolilli JJ, O'Hara GW, Tiwari RP, Dilworth MJ, Howieson JG (2008) The model legume Medicago truncatula A17 is poorly matched for $\mathrm{N}_{2}$ fixation with the sequenced microsymbiont Sinorhizobium meliloti 1021. New Phytol 179:62-66

Tice KR, Parker DR, DeMason DA (1992) Operationally defined apoplastic and symplastic aluminum fractions in root tips of aluminum-intoxicated wheat. Plant Physiol 100:309-318

Van de Wiel C (1991) A histochemical study of root nodule development. PhD. thesis, Wageningen Agricultural University

Vartapetian BB, Andreeva IN, Generozova IP, Polyakova LI, Maslova IP, Dolgikh YI, Stepanova AY (2003) Functional electron microscopy in studies of plant response and adaptation to anaerobic stress. Ann Bot 91:155-172

Vasse J, de Billy F, Camut S, Truchet G (1990) Correlation between ultrastructural differentiation of bacteroids and nitrogen fixation in alfafa nodules. J Bacteriol 8:4295-4306

Vázquez MD, Poschenrieder C, Corrales I, Barceló J (1999) Change in apoplastic aluminum during the initial growth response to aluminum by roots of a tolerant maize variety. Plant Physiol 119:435-444

Wagatsuma T, Kaneko M, Hayasaka Y (1987) Destruction process of plant root cells by aluminum. Soil Sci Plant Nutr 33:161-175

Wang Y, Staß A, Horst WJ (2004) Apoplastic binding of aluminum is involved in silicon-induced amelioration of aluminum toxicity in maize. Plant Physiol 136:3762-3770

Yamamoto Y, Kobayashi Y, Matsumoto H (2001) Lipid peroxidation is an early symptom triggered by aluminum, but not the primary cause of elongation inhibition in pea roots. Plant Physiol 125:199-208

Zheng SJ, Yang JL (2005) Target sites of aluminum phytotoxicity. Biol Plant 49:321-331 